\title{
Anselm's Influence on the Teaching of the Summa Halensis on Redemption
}

\begin{abstract}
It has long been recognized that the Summa Halensis was one of the first texts to extensively engage the arguments of Anselm's Cur Deus homo. As a result of this engagement, Anselm can rightly be thought of as exercising a great deal of influence on how the Summa understands Christ's redemptive work. We see this influence, for instance, when the Summa takes up questions Anselm poses about redemption, such as whether satisfaction is necessary for sin or whether only a God-man can make satisfaction. Without denying the influence of Anselm on the soteriology of the Summa Halensis, this chapter focuses primarily on how the Summa both modifies Anselm's ideas and supplements them. Thus, I examine how the Summa employs the distinction between God's absolute and ordained power to modify Anselm's claims regarding the manner in which certain aspects of God's plan of redemption are deemed necessary. Also, I show that Peter Lombard's Sentences significantly shape how the Summa interprets what Anselm writes about Christ's satisfaction and merit. Finally, I consider how the Summa draws on other authorities such as Gregory the Great and John Damascene to supplement Anselm's account of redemption.
\end{abstract}

Alexander of Hales was one of the first $13^{\text {th }}$-century theologians to closely examine Cur Deus homo and treat Anselm as a significant theological authority. Anselm's treatise is cited extensively in Alexander's Glossa and in his disputed questions. Yet Anselm's Cur Deus homo has an even greater presence in the Summa Halensis (SH) than it does those earlier works. Michael Robson, who has documented the influence of Anselm among early Franciscan theologians, writes, 'A barometer of the growing influence of Anselm on the nascent Franciscan school is strikingly present in Book 3 of the Summa Fratris Alexandri, whose early questions presuppose a close reading of the Cur Deus homo.' Similarly, J. Patout Burns writes that in the SH 'Anselm comes into his own as the master of teaching on redemption'. ${ }^{2}$ Anselm did exercise a great amount of influence on how the $S H$ understands Christ's redemptive work. The $S H$, for instance, adopts Anselm's claim that making satisfaction is central to

1 Michael Robson, 'Odo Rigaldi and the Assimilation of St. Anselm's Cur Deus homo in the School of the Cordeliers in Paris,' in Saint Anselm and his Legacy, ed. Giles E.M. Gasper and Ian Logan, Durham Medieval and Renaissance Mongraphs and Essays, 2 (Toronto: Pontifical Institute of Mediaeval Studies, 2012), 165. For more on the place of the Summa Halensis in the reception of Cur Deus homo, see Brian P. McGuire, 'The History of Saint Anselm's Theology of the Redemption in the Twelfth and Thirteenth Centuries' (D.Phil. thesis, University of Oxford, 1970).

2 J. Patout Burns, 'The Concept of Satisfaction in Medieval Redemption Theory,' Theological Studies 36 (1975): 293.

D OpenAccess. (c) 2020 Lydia Schumacher, published by De Gruyter. (c))BY-NC-ND This work is licensed under the Creative Commons Attribution-NonCommercial-NoDerivatives 4.0 License. 
Christ's redemptive work. Yet the way that the teachings of Cur Deus homo were incorporated into the $S H$ were affected by theological principles unique to the $S H$ and by the ideas of other important theological authorities. As a result the $\mathrm{SH}$ modifies and supplements Anselm's Cur Deus homo in various ways as it puts forward its own teaching on Christ's redemptive work. In what follows I will focus on three ways that the $S H$ incorporates and modifies Anselm's Cur Deus homo. First, I will examine how the $\mathrm{SH}$ uses the distinction between God's absolute and ordained power to modify Anselm's claims regarding the manner in which certain aspects of God's plan of redemption are deemed necessary. Second, I will show that Peter Lombard's Sentences significantly shape how the $S H$ interprets what Anselm writes about Christ's satisfaction and merit. Finally, I will consider how the $S H$ draws on other authorities such as Gregory the Great and John Damascene to supplement Anselm's account of redemption.

\section{The Necessity of God's Plan of Redemption}

In Cur Deus homo $(\mathrm{CDH})$ Anselm argues that many aspects of God's plan of redemption are necessary. Anselm is aware that this would seem to conflict with God's omnipotence, and for this reason Anselm distinguishes a necessity arising from external coercion from a necessity arising from God's immutability. When Anselm argues that it is necessary that God restore human nature, the necessity in question is not a result of God being externally coerced, but of God immutably acting in accord with his wisdom. For, according to Anselm, it would have been unwise of God to create human beings for eternal life, and then to let them all perish in eternal damnation. While God is unable to act against his wisdom, this is not a sign of weakness, but of his perfect power.

The $S H$ also attributes a necessity of immutability to God, and this necessity applies to his decision to restore human nature. ${ }^{3}$ For the $S H$, however, the necessity of immutability refers to God's consistently and unfailingly willing whatever he has chosen to will from among the several possible things he might have willed. Thus, this understanding of the necessity of immutability does not preclude God's ability to have chosen otherwise than he did. The SH argues that God could have chosen to permit the damnation of the entire human race. This was not so for Anselm. As William Courtenay writes,

for Anselm, God does not have the ability to will that which he has not willed or that which is contrary to his nature. For Anselm only one way was ever really correct or possible, for God's

3 Alexander of Hales, Doctoris irrefragabilis Alexandri de Hales Ordinis minorum Summa theologica (SH), 4 vols (Quaracchi: Collegium S. Bonaventurae, 1924-48), Vol IV, P1, In1, Tr1, Q1, M3, C3 (n. 3), Respondeo, p. 14a [a and b refer to the left and right columns respectively]. 
will has to express God's nature, and God's nature in turn can never have been subject to multiple possibilities. ${ }^{4}$

Nevertheless, the $S H$ claims to find a basis in $C D H$ I.15 for its own interpretation of the necessity of immutability. In this place Anselm states that fallen humans and angels who do not wish to submit to the divine will and its order cannot ultimately escape it. For if they seek to escape God's ordering will, they will become subject to his punishing will. Even though Anselm's point seems to have been that it is futile in the end to try to escape God's will, the $S H$ takes Anselm to support the conclusion that God could have chosen to let the whole human race suffer eternal punishment. For, according to the $S H$, God has the power to either order the human race to beatitude through his justice and mercy or instead order the human race to punishment through divine justice. ${ }^{5}$

Another side of the SH's understanding of divine power surfaces when it investigates whether it is necessary that there be satisfaction for sin. According to the $S H$ the statement 'God cannot restore human nature without satisfaction' can be interpreted in two ways depending upon whether God's power is being considered absolutely or with order. ${ }^{6}$ The $S H$ states, 'taking divine power absolutely, we intend a certain infinite power, and in this sense nothing determines divine power, and in this sense it is conceded that he could restore human nature without satisfaction for sin. ${ }^{7}$ Divine power, however, can also be considered 'with order', and in this sense it is considered with respect to justice and mercy. While God can do nothing that is not in accord with his justice and mercy, the $S H$ makes a further distinction with regard to what is meant by saying that God must act in accord with his justice. For God's ability to do something from justice can be referred either to his essence or to how he has decided to manifest his justice and mercy with respect to his creatures. According to the $\mathrm{SH}$, 'the ability from justice can be referred to its principal significate, which is the divine essence, and, then, the ability from justice is the same as the ability from power, and in this way he could [forgive sins without satisfaction]. ${ }^{8}$ Yet God's ability to act with justice can also be referred to how he has decided to relate to

\footnotetext{
4 William Courtenay, 'Necessity and Freedom in Anselm's Conception of God,' Analecta Anselmiana 45 (1975): 62.

5 SH IV, P1, In1, Tr1, Q1, M3, C3 (n. 3), Ad obiecta 2-4, p. 14b.

6 For the role of the $S H$ in the development of this distinction, see William Courtenay, Capacity and Volition: A History of the Distinction of Absolute and Ordained Power (Bergamo: Lubrina, 1990), 73-7. See also Corey L. Barnes, 'Necessary, Fitting, or Possible: The Shape of Scholastic Christology,' Nova et Vetera, English Edition, 10 (2012): 657-99.

7 SH IV, P1, In1, Tr1, Q1, M4, C4 (n. 4), Respondeo, p. 15b: 'Considerando divinam potentiam absolute cogitamus quamdam virtutem infinitam, et secundum hunc modum non est determinare divinam potentiam, et conceditur hoc modo quod potest reparare humanam naturam sine peccati satisfactione.' 8 SH IV, P1, In1, Tr1, Q1, M4, C4 (n. 4), Respondeo, p. 16a: '(...) potest referri "posse de iustitia” ad principale significatum, quod est divina essentia, et tunc idem est posse de iustitia quod posse de potentia, et hoc modo potest.'
} 
creatures, and in this way God gives to each what he deserves. Assuming the decision to give each creature what it deserves, it would be unjust for God to forgive sin apart from satisfaction since of itself sin deserves punishment rather than reward. ${ }^{9}$ Given his decision to manifest his justice with respect to creatures in this way, God is unable to restore human nature without satisfaction. Here again the $S H$ claims to reach a conclusion consistent with Anselm. ${ }^{10}$

In its explanation of both the sense in which it was necessary that God restore human nature and necessary that there be satisfaction, the $S H$ relies on an understanding of the relation of divine power to alternative possibilities that seems foreign to Anselm's way of understanding divine omnipotence. Yet, as we have seen, the $S H$ presents its own teaching as being in continuity with that of Anselm's. This is also the case with its answer to the question of whether God acts justly in permitting his innocent Son to suffer. The $S H$ cites Anselm's treatment of that question from $\mathrm{CDH}$ I.8, where Anselm argues that the Son's suffering is just because it is voluntary. ${ }^{11}$ The $S H$ accepts this interpretation, but goes on to claim that God's absolute power sheds further light on the question: 'To the solution of Anselm we must add the following: by referring to absolute divine power there would be no injury in punishing the innocent, according to what the Apostle says in Rom. 9:21: "Surely the potter has power etc.”, because no action of God could be unjust." ${ }^{, 2}$ The $S H$ presents its own

9 SH IV, P1, In1, Tr1, Q1, M4, C4 (n. 4), Ad obiecta 5, pp. 16b-7a.

10 SH IV, P1, In1, Tr1, Q1, M4, C4 (n. 4), Respondeo, p. 16a: 'Si autem referatur ad connotatum, dicit Anselmus quod tunc "posse de iustitita” est posse secundum congruentiam meritorum, et hoc modo dicit idem Anselmus: "Non potest Deus peccatum impunitum sine satisfactione dimittere nec peccator ad beatitudinem, qualem habiturus erat ante peccatum, poterit pervenire"' [If it is referred to the thing indicated, then Anselm says that the "ability from justice" is an ability according to the congruity of merits, and Anselm says the same thing in this way: "God is not able to forgive unpunished sin without satisfaction nor could a sinner achieve a beatitude of the sort that he was about to have prior to $\sin "]$.

11 SH IV, P1, In1, Tr5, Q1, M4, C1, Ar1 (n. 151), arg. 1, p. 211a-b.

12 SH IV, P1, In1, Tr5, Q1, M4, C1, Ar1 (n. 151), Ad obiecta 1, p. 212b: 'Est tamen addendum ad solutionem Anselmi, quod referendo ad potentiam divinam absolutam, nulla esset iniuria punire innocentem, secundum quod dicit Apostolus, Rom. 9, 21: "Numquid potestatem habet figulus etc.", quia nulla actio Dei potest esse iniusta.' See also SH I, P1, In1, Tr4, Q2, M2, C2 (n. 141), pp. 220b1a: 'Ad illud vero quod quaerit "utrum possit damnare Petrum” etc., distinguendum quod potentia Dei intelligitur dupliciter: uno modo absoluta, alio modo ordinata secundum rationem divinae praeordinationis iustitiae reddentis unicuique secundum merita. De potentia ergo absoluta posset damnare Petrum et salvare Iudam; de potentia vero ordinata secundum praeordinationem et retributionem secundum merita, not posset; nec in hoc derogatur eius potentiae, sed ostenditur immutabilitas ordinis potentiae secundum praeordinationem et iustitiam' [But to that which is asked, namely, "whether [God] could damn Peter, etc.", we must distinguish between two ways of understanding God's power: in one way [it is considered] absolutely, in another way as it is ordered by what he has foreordained according to divine justice whereby he returns to each according to his or her merits. Therefore, de potentia absoluta he could have damned Peter and saved Judas. Yet he could not do this de potentia ordinata according to what he foreordained and according to what is owed for one's 
teaching as being consistent with Anselm's, and merely as providing a resolution of the question to a more fundamental principle. Yet in coming to this conclusion and others that rely on the distinction between God's absolute and ordained power, the SH has modified Anselm's teaching on the necessity of God's plan of redemption in accord with an understanding of divine power that is more commonly associated with later Franciscan theologians like Duns Scotus and William of Ockham. ${ }^{13}$

\section{Satisfaction and Merit}

The $S H$ attributes a significant role to satisfaction and merit in its explanation of how Christ's death redeems the human race. Naturally the SH often cites Anselm's CDH when talking about Christ's satisfaction for sin. There is even a basis in CDH II.19 for some of what the $\mathrm{SH}$ says regarding Christ's merit of human salvation. As we shall see, however, the $S H$ interprets Anselm's teachings about satisfaction and reward in light of what Peter Lombard writes about Christ's redemptive work in III Sentences, Distinctions 18-19. It seems as if the authors of the $S H$ sought to produce a synthesis of Anselm's and the Lombard's teaching on redemption. ${ }^{14}$

The $\mathrm{SH}$ claims that divine justice requires Christ to make satisfaction through suffering. According to the $\mathrm{SH}$, 'the justice of God is such that he never forgives sin without punishment. For sin is not ordered except through punishment, according to what Augustine says in the book De natura boni: "sins are ordered in punishments". ${ }^{15}$ The $S H$ goes on to say that God's justice can be manifested in two different ways in the face of sin. First, God's justice could be manifested through eternally punishing sinners. Second, if God were to punish sins temporally, then this would manifest his justice and mercy. ${ }^{16}$ For this reason the $S H$ teaches that making satisfaction necessarily involves freely accepting some sort of temporal punishment. ${ }^{17}$

merits. There is no restriction of his power in this, but what is shown through this is the immutability of the order of his power according to his foreordaining and his justice].

13 For Scotus' soteriology, see Andrew V. Rosato, 'The Teaching of Duns Scotus on whether only a God-Man could make Satisfaction for Sin,' The Thomist 79 (2015): 551-84. See also Thomas M. Ward, 'Voluntarism, Atonement, and Duns Scotus,' The Heythrop Journal 58 (2017): 37-43.

14 For the Lombard's contribution to the theology of redemption, and his relation to Anselm, see Marcia L. Colish, Peter Lombard, 2 vols, Brill's Studies in Intellectual History, 41 (Leiden: Brill, 1994), 1:448-70.

15 SH IV, P1, In1, Tr5, Q1, M4, C1, Ar1 (n. 151), Respondeo, p. 212a: 'Dei enim iustitia est, ut nunquam peccatum dimittatur sine poena. Peccatum enim non ordinatur nisi in poena, secundum quod dicit Augustinus, in libro De natura boni: "Peccantes in suppliciis ordinatur".'

16 SH IV, P1, In1, Tr5, Q1, M4, C1, Ar1 (n. 151), Respondeo, p. 212a.

17 SH IV, P1, In1, Tr1, Q1, M6, C5, Ar2 (n. 6), Respondeo, p. 20a: 'Ad satisfactionem peccati requiritur gratia Dei, per quam fit absolutio reatus aeterni et sustinentia poenae temporalis: primum est ex Dei misericordia, secundum ex iustitia' [For the satisfaction of sin the grace of God is required, through which absolution for eternal guilt comes about, and the enduring of temporal punishment: the first is from the mercy of God, the second from his justice]. 
This way of understanding the relation between punishment and making satisfaction is different from what we find in $\mathrm{CDH}^{18}{ }^{18}$ Anselm speaks of God requiring either satisfaction or punishment because of sin, and this disjunction suggests that undergoing punishment is not essential to satisfaction. ${ }^{19}$ For Anselm it is performing some supererogatory act for God's honor that is essential to making satisfaction. Anselm argues that the God-man's mode of making satisfaction involved suffering and death because there was nothing else that he was not already obligated to offer for the honor of God.

Although in $C D H$ II.19 Anselm does briefly mention that the death of the Godman earns a reward that redounds to human salvation, the $S H$ draws explicitly on Peter Lombard when addressing questions about Christ's merit. One reason for this is no doubt that Peter Lombard presents a more detailed analysis of Christ's redemptive merit than Anselm does. The influence of Peter Lombard on the understanding of Christ's merit in the $S H$ is evident in the following passage:

\begin{abstract}
Merit, with respect to its power, depends upon charity. With respect to its effect, however, it depends upon a work caused by charity, either an interior work, such as an act of will, or an exterior one such as to do or to suffer something. With regard to Christ's power to merit, he merits as much before his passion as he does in his passion. With regard to the effect of his merit, however, he merits more [in his Passion], that is [he merits] more things or in more ways, according to what the Master says in Distinction 18 of Book 3 of his Sentences: "he does not advance with respect to the power to merit" but "with respect to the number of things merited" ${ }^{20}$
\end{abstract}

Christ's power to merit remains constant throughout his life because he always possesses the fullness of charity. Yet Christ does add to the things he merits over the course of his life, and some of what he merits both for himself and for us comes through choosing to suffer on behalf of the human race. ${ }^{21}$

The $S H$ sets out in detail how Christ's satisfaction and merit bring about human salvation when addressing the question of how Christ justifies sinners. The $S H$ begins

18 For more on the understanding of satisfaction in the $S H$ and the early Franciscans, see Andrew V. Rosato, 'The Interpretation of Anselm's Teaching on Christ's Satisfaction for Sin in the Franciscan Tradition from Alexander of Hales to Duns Scotus,' Franciscan Studies 71 (2013): 411-44; and Lydia Schumacher, Early Franciscan Theology: Between Authority and Innovation (Cambridge: Cambridge University Press, 2019): 212-41.

19 Anselm of Canterbury, Cur Deus homo I, c. 13, in S Anselmi Cantuariensis archiepiscopi opera omnia, vol. 2, ed. Franciscus Salesius Schmitt (Edinburgh: Nelson, 1946), 71-2.

20 SH IV, P1, In1, Tr4, Q3, M3, C3 (n.134), Respondeo, pp. 186b-7a: 'Meritum, quantum ad virtutem, consistit penes caritatem; quantum vero ad effectum consistit in opere, movente caritate, sive sit opus interius, sicut voluntas, sive exterius, quantum ad agere et pati. Attendendo ergo ad virtutem meriti, tantum meruit Christus ante passionem quantum in passione. Attendendo vero ad effectum meriti, plus meruit, id est pluribus modis sive in pluribus, secundum quod dicit Magister, in Sententiis, dist. 18 III libri, quod "non profecit quantum ad virtutem meriti", sed "quantum ad numerum meritorum”.' See also SH IV, P1, In1, Tr5, Q1, M3, C2 (n. 149), Ad obiecta 2, p. 210a.

21 SH IV, P1, In1, Tr4, Q3, M4, C2, Ar2 (n. 139), Ad obiecta 1-4, p. $192 \mathrm{~b}$. 
by distinguishing two ways of considering Christ's Passion. It can be considered as a historical event, but also as something that comes to exist in the soul in some way. In other words, the $\mathrm{SH}$ is distinguishing the Passion as an event that in itself makes satisfaction and merits grace, but nevertheless still needs to be appropriated in some way by individual sinners who seek justification through Christ. ${ }^{22}$

As a historical event, the passion of Christ overcomes sin in two ways. These two ways correspond to two aspects of sin, namely sin as incurring a debt to punishment and $\sin$ as staining the soul. ${ }^{23}$ By making satisfaction for sin, the passion frees human beings from the punishment due to $\sin .{ }^{24}$ The $S H$ speaks of Christ's passion as removing the temporal punishment due to original sin, as removing the debt to eternal punishment, and even in some sense as removing temporal punishment for sin here and now for Christians. The $S H$ acknowledges that if an individual human person were given grace, then he or she could offer satisfaction for personal sins. ${ }^{25}$ Original sin, however, is a different kind of sin since it affects human nature as such, and therefore, the one who can make satisfaction for it must be able to reorder the whole of human nature to God. ${ }^{26}$ This is something only a God-man could do because only such a being could offer a satisfaction equivalent to the debt incurred by original sin. ${ }^{27}$ The satisfaction of Christ has such great value in virtue of both his divine person and in virtue of the infinite grace his human soul possesses. ${ }^{28}$ In making satisfaction, then, Christ simultaneously pays the debt to temporal punishment incurred by original sin and overcomes our debt to eternal punishment. The $S H$ also sees some relaxation to the temporal punishment of sinners in this life insofar as a Christian is no longer under the dominion of death, and, therefore, need not fear death. ${ }^{29}$ The $S H$ holds up the martyrs as especially exemplifying this effect of Christ's satisfaction.

22 SH IV, P1, In1, Tr5, Q1, M6, C1, Ar1 (n. 156), Respondeo, p. 216a: 'Passio Christi se habet ad remissionem peccati pluribus modis. Est enim passio Christi dupliciter: in rei natura et in anima' [The passion of Christ is related to the remission of sins in many ways. For the passion of Christ exists in two ways: in its own right and in the soul].

23 SH IV, P1, In1, Tr5, Q1, M6, C1, Ar1 (n. 156), Respondeo, p. 216a: 'In peccato autem sunt duo, macula et reatus: macula quae est deformitas vel dissimilitudo ad Deum; reatus obligatio ad poenam' [There are two aspects of sin, namely its stain and its guilt: the stain which is a deformity or unlikeness to God, and the guilt which brings about an obligation to punishment].

24 SH IV, P1, In1, Tr5, Q1, M6, C1, Ar1 (n. 156), Respondeo, p. 216a: 'Est etiam causa satisfactoria reatus poenae, secundum quod dicitur Isaiah 53:4: "Vere languores nostros ipse tulit etc.”' [The guilt obligating punishment is also a satisfactory cause, according to what is said in Isaiah 53:4, "Truly he bore our infirmities, etc."].

25 SH IV, P1, In1, Tr1, Q1, M5, C5, Ar1 (n. 5), pp. 17b-8a.

26 SH IV, P1, In1, Tr1, Q1, M5, C5, Ar2 (n. 6), p. 20a.

27 SH IV, P1, In1, Tr1, Q1, M9, C7 (n. 9), pp. 23-4.

28 SH IV, P1, In1, Tr4, Q3, M4, C2, Ar2 (n. 139), p. 192b.

29 SH IV, P1, In1, Tr4, Q3, M4, C2, Ar3 (n. 140), Respondeo, p. 193b: 'Sed et dominium mortis temporalis destruxit in pluribus; ita enim dominabatur mors prius quod timore mortis retro abibant, sed post factum est ut non timeretur, sed gratanter currerent ad mortem, quod in martyribus claruit' 
The other way that Christ's death overcomes sin involves removing the stain of sin that deforms the human soul. This occurs through Christ meriting grace for sinners. As the SH states, 'the passion of Christ is a meritorious cause of removing the stain [of $\sin$ ] because he merits grace and everything else for us by which sin is removed. ${ }^{30}$

After setting out these two ways that Christ's passion brings about justification, the $S H$ quotes a long passage from $C D H$ II.14, where Anselm speaks of Christ's life as so good and so worthy of love that it can overcome the sins of the whole world. The SH offers the following Gloss on Anselm's words: 'Therefore, the passion of Christ in itself destroys sin as a meritorious cause of grace that removes its stain and as a satisfactory cause that destroys the obligation to punishment. ${ }^{31}$ With these words the $\mathrm{SH}$ recapitulates what we have already seen as its own way of describing the twofold manner in which the Passion destroys sin, and here it attributes this same teaching to Anselm. While what Anselm says in $C D H$ II.14 and elsewhere is compatible with the position of the $S H$, it is noteworthy that Anselm does not distinguish the stain of sin from the punishment due to sin nor does he distinguish the temporal punishment due to sin from the eternal punishment. Thus, Anselm does not describe some aspects of Christ's death as addressing the stain of sin, and other aspects as addressing the punishment due to sin. These ways of analyzing the passion of Christ are found, however, in III Sentences Distinctions 18 to 19. For example, in Chapters 3 to 4 of III.19, the Lombard speaks of how Christ's death is related to overcoming the temporal and eternal punishments due to $\sin .^{32}$

Peter Lombard also influences how the $S H$ explains the manner in which the fruits of Christ's passion are appropriated by individuals. The $S H$ states that Christ's passion removes sin insofar as it exists in the soul of the person through love, faith, compassion, and imitation. According to the SH, 'in these four ways [Christ's passion] is joined to the soul and has existence in it. ${ }^{33}$ The $S H$ refers to the Sentences

[But he also destroyed in many ways the temporal dominion of death. For death was dominating to such an extent that they were turning back out of a fear of death, but after it was done they did not fear, but voluntarily ran to death, as is clear in the case of the martyrs].

30 SH IV, P1, In1, Tr5, Q1, M6, C1, Ar1 (n. 156), Respondeo, p. 216a: 'Est ergo Christi passio causa meritoria deletionis maculae quia meruit nobis gratiam et omne illud quo deletur peccatum.'

31 SH IV, P1, In1, Tr5, Q1, M6, C1, Ar1 (n. 156), Respondeo, p. 216b: 'Sic ergo passio Christi in ipsa natura rei delet peccatum ut causa meritoria gratiae ad delendum maculam et ut causa satisfactoria ad delendum reatum ad poenam.'

32 Peter Lombard, Sententiae in IV libris distinctae 3, d. 19, cc. 3-4, 2 vols, ed. Ignatius C. Brady, Spicilegium Bonaventurianum, 3-4 (Grottaferrata: Collegium S. Bonaventurae, 1971-81), 2:121-2. See also Peter Lombard, Sententiae 3, d. 18, c. 5 (Brady, 2:116): 'Meruit enim nobis per mortis ac passionis tolerantiam quod per praecedentia non meruerat, scilicet aditum paradisi et redemptionem a peccato, a poena, a diabolo' [By undergoing his passion and death, he merits for us certain things he had not previously merited, namely the opening of paradise, redemption from sin, punishment, and the devil].

33 SH IV, P1, In1, Tr5, Q1, M6, C1, Ar1 (n. 156), Respondeo, p. 216b: 'Istis enim quatuor modis coniungitur animae et habet esse in illa.' 
in its explanation of the first two ways, and its own analysis of how love and faith remove sin closely follows what the Lombard writes in Sentences, Book 3, Distinction 19. ${ }^{34}$ Peter Lombard refers to Rom. 5:8 where Paul writes that God commended his charity towards us by dying for us when we were sinners. The $\mathrm{SH}$ also cites this passage from Romans, and the $S H$ follows Peter Lombard's interpretation of the passage according to which the death of Christ justifies us by enkindling charity in our hearts through its own example of love for us. ${ }^{35}$

When explaining how faith justifies the sinner, the $S H$ follows Peter Lombard's teaching from Chapter 1 of III.19, using again a passage from Romans that Peter Lombard cites to support its claims. Faith in Christ's death is an efficient cause for removing the stain of sin since such a faith is conjoined to charity. ${ }^{36}$ The $S H$ interprets Rom. 3:22-25 to suggest that faith in Christ's passion has this power: '[the stain of sin] is removed in adults through their own faith, or with the sacrament of faith, as in Baptism, that removes the stain in children through the faith of the Church. Thus, the Apostle in Romans 3:22-25, "the justice of God" is "by faith in Jesus whom [God] proposed as a propitiator through faith in his blood", that is, through faith in the passion. ${ }^{37}$

Faith and charity remove the stain of sin in the soul. The other aspect of sin-the obligation to punishment-has been overcome by Christ in the ways described above, but once a baptized person falls into sin again he or she incurs a new debt to punishment. This new debt is overcome through the passion of Christ having existence in the person through both compassion and imitation. The $\mathrm{SH}$ indicates that

34 SH IV, P1, In1, Tr5, Q1, M6, C1, Ar1 (n. 156), Respondeo, p. 216b: 'Passio ergo Christi duobus modis valet ad deletionem peccati, sicut dicit Magister, in III Sententiarum, 18 [sic] dist. Primus modus est ex parte caritatis, secundus ex parte fidei' [Therefore, the passion of Christ can delete $\sin$ in two ways, just as the Master says in III Sentences d. 18 [sic]: the first way is from charity, the second from faith]. 35 SH IV, P1, In1, Tr5, Q1, M6, C1, Ar1 (n. 156), Respondeo, p. 216b: 'Primus modus est ergo ex parte caritatis, quia per passionem Christi excitatur in nobis amor Dei, secundum quod Apostolus, Rom 5:8, "Commendat Deus caritatem suam in nobis, quoniam, cum essemus peccatores, Christus pro nobis mortuus est." Et ex hoc accendimur ad amandum ipsum amore caritatis, quae "operit multitudinem peccatorum" [1 Peter 4:8]' [The first way is from charity because through the passion of Christ the love of God is roused in us, as the Apostle writes in Romans 5:8, "God commends his charity to us because when we were sinners, Christ died for us." From this we are inflamed to love of him with the love of charity, which "covers a multitude of sins" (1 Peter 4:8)]. Cf. Peter Lombard, Sententiae 3, d. 19, c. 1 (Brady, 2:118).

36 SH IV, P1, In1, Tr5, Q1, M6, C1, Ar1 (n. 156), Respondeo, p. 216b: 'Ex parte vero fidei ostenditur modus per modum efficientis, quia passio Christi per fidem formatam, quae est cum amore Dei, valet ad deletionem maculae peccati ut causa effectiva coniuncta' [On the part of faith this occurs through the mode of efficiency, because the passion of Christ (through formed faith, which is with the love of God) can delete the stain of $\sin$ as an effective conjoined cause]. Even though God alone is the principal cause of removing the stain of sin, the $S H$ describes the passion as a cooperating efficient and meritorious cause of this (see SH IV, P1, In1, Tr5, Q1, M6, C1, Ar1 (n. 156), Ad obiecta 1, p. 217a).

37 SH IV, P1, In1, Tr5, Q1, M6, C1, Ar1 (n. 156), Respondeo, p. 216b. 
compassion is an interior act that serves as a meritorious cause of the remission of sins whereas imitation of Christ's passion occurs through an external act whereby one makes satisfaction to pay the debt of punishment incurred by $\sin .^{38}$ There is no parallel in III Sentences, Distinctions 18 to 19 to what the $S H$ writes about how Christ's passion exists in the soul through compassion and imitation. It does bear some similarities to what Peter Lombard writes in IV Sentences, Distinction 16 about the compunction of heart and satisfaction in deed that form two of the three parts of penance. Regardless of whether that lies in the background, it is clear that the $\mathrm{SH}$ goes beyond the teaching of $\mathrm{CDH}$ in discussing how Christ's passion is appropriated by individuals, and, as we have seen, its discussion of this aspect of Christ's redemptive work is influenced by what Peter Lombard writes about faith and charity.

\section{The Magnitude of Christ's Suffering}

The connection between punishment and satisfaction leads the $S H$ to explore questions about the manner and degree of Christ's suffering not addressed by Anselm. In answering these questions, the $S H$ will nevertheless sometimes draw on resources from the $C D H$ in addition to resources provided by other theological authorities such as Peter Lombard and John Damascene.

When considering which type of suffering would constitute an adequate satisfaction for sin, the $\mathrm{SH}$ asks if Christ could make satisfaction by the shedding of a single drop of blood. It attributes the following argument to Bernard of Clairvaux: 'One drop of blood was a sufficient price for our redemption. Therefore, after his circumcision, it was not necessary for him to suffer. ${ }^{39}$ In response to this, the $S H$ distinguishes between two ways of determining the adequacy of the suffering offered as satisfaction for sin. If considered from the perspective of the person suffering, then one drop of blood would suffice since the person suffering is God. In determining the value of Christ's suffering in relation to the divine person who undergoes the suffering, the SH follows Anselm's way of understanding why Christ's satisfaction was able to pay the debt of $\sin .{ }^{40}$ Yet the $S H$ notes that the adequacy of one's satisfaction

38 SH IV, P1, In1, Tr5, Q1, M6, C1, Ar1 (n. 156), Respondeo, pp. 216b-7a: 'Passio vero Christi in compassione et imitatione vel per compassionem et imitationem valet ad deletionem reatus poenae; sed compassio interior, ut causa meritoria remissionis poenae; imitatio in actu exteriori, ut causa satisfactoria poenae debitae' [The passion of Christ in compassion or imitation or through compassion and imitation could delete the guilt for punishment; but interior compassion does this as a meritorious cause of the remission of punishment, while imitation in exterior act does this as a satisfactory cause for the debt to punishment].

39 SH IV, P1, In1, Tr5, Q1, M3, C2 (n. 149), arg. 3, p. 209a: 'Item, Bernardus: Una gutta sanguinis sufficiens fuit pretium nostrae redemptionis; ergo post circumcisionem non fuit necesse eum pati.' 40 Anselm of Canterbury, Cur Deus homo II, c. 14 (Schmitt, 113-6). 
could also be considered according to the kind of punishment suffered. In this sense one drop of blood would not be sufficient. For 'in satisfaction the kind of punishment ought to correspond to the kind of guilt." ${ }^{41}$ The severity of human guilt would make it unfitting for satisfaction to be made through the shedding of a single drop of blood. An adequate satisfaction requires that Christ undergo the greatest suffering.

In addition to discussing the magnitude of Christ's suffering, the $S H$ explores the types of suffering that Christ could have undergone. The $S H$ first distinguishes culpable suffering from penal suffering.$^{42}$ Culpable suffering is suffering for one's own guilt, while penal suffering is the suffering imposed on the human race because of original sin. Christ did not experience every kind of suffering because none of his suffering was culpable suffering. He did undergo some, but not all, types of penal suffering. Following Peter Lombard, the $S H$ divides penal suffering into suffering that detracts from one's dignity and suffering that does not do so. ${ }^{43}$ The types of suffering which detract from one's dignity are either those that are so overwhelming that one's reason is disturbed or those that stem from some type of ignorance. Christ freely takes on sufferings such as hunger, thirst, and sorrow that do not detract from his dignity and that will contribute to his work of redemption. These types of suffering along with willingly accepting death contribute in different ways to his salvific work.

The $S H$ uses John Damascene's distinction between the natural and rational will to explain the magnitude of suffering involved in Christ's death. The severity of Christ's experience of suffering can be determined in two different ways depending upon whether it was contrary to his natural will only or both his natural will and his rational will. In the first way, Christ experienced the greatest suffering. To say that Christ's bodily suffering was against his natural will indicates that Christ's soul (like that of any human being) is naturally inclined to union with its body, and opposed to separation from it. Yet Christ's death is uniquely painful, according to the $\mathrm{SH}$, because 'his body had the best construction and was optimally suited to its soul. ${ }^{44}$ Christ's death, however, was not against his rational will, and insofar as it

41 SH IV, P1, In1, Tr5, Q1, M3, C2 (n. 149), Ad obiecta 3, p. 210b: 'In satisfactione autem respondere debet genus poenae generi culpae.'

42 SH IV, P1, In1, Tr5, Q1, M2, C2, Ar1 (n. 147), Respondeo, p. $204 \mathrm{a}-\mathrm{b}$.

43 Peter Lombard, Sententiae 3, d. 15, c. 1 (Brady, 2:93): 'Suscepit autem Christus sicut veram naturam hominis, ita et veros defectus hominis, sed non omnes. Assumpsit enim defectus poenae, sed non culpae; nec tamen omnes defectus poenae, sed eos omnes quos homini eum assumere expediebat et suae dignitati non derogabat' [Just as Christ took on the true nature of man, so also he took on the true defects of man, but not all of them. For he assumed the defects of punishment, but not of guilt. He did not take on all the defects of punishment, but all those which it was suitable for him to assume as man and which did not detract from his dignity].

44 SH IV, P1, In1, Tr5, Q1, M5, C1 (n. 154), Respondeo, p. 214b. 
was in accord with his rational will, he did not suffer. Indeed, the ability of his suffering to contribute to human redemption depends precisely on its being willed. ${ }^{45}$

\section{The Salvific Significance of Christ's Incarnation, Life, and Resurrection}

Anselm focuses on explaining how the death of a God-man is necessary for human salvation. While Christ's suffering and death is the main focus of the SH's treatment of redemption, it also investigates the redemptive significance of the Incarnation itself as well as the redemptive significance of the earthly life and resurrection of Christ.

The $S H$ asks whether the Incarnation itself accomplishes human salvation. An argument for this is based on Gregory the Great's statement that the humility of the redeemer should be as great as the pride of the sinner. On this basis the $S H$ develops the following argument: 'that his humility was at least as great is clear because Adam wished to ascend to deity not in the union of person, but through conforming in knowledge [to God]. But God descends to us even up to the union with a human [nature]. ${ }^{46}$ Adam's pride sought a union with God in terms of knowledge, but the Logos' humility sought an even more intimate union with humanity, a union in person rather than merely a union of knowledge. Thus, according to the $S H$, to the extent that our salvation requires an act of humility that outweighs the pride of Adam's sin, then the humility evinced in the Incarnation itself more than suffices. ${ }^{47}$

The $S H$ also sees redemptive significance in the suffering Christ underwent prior to his death on the cross. ${ }^{48}$ The $S H$ locates the importance of this suffering in redressing the perverse enjoyment (perversa delectatio) present in Adam's sin. ${ }^{49}$ This perverse enjoyment was manifested in a spiritual way through desiring to eat the fruit, and in a material way through eating the fruit. The perverse enjoyment in something physical is remedied by Christ's suffering at different moments in his life. As an example of this, the $S H$ points to Luke 19:41, where Christ cries over Jerusalem's re-

45 SH IV, P1, In1, Tr5, Q1, M5, C1 (n. 154), Respondeo, p. 214b: 'secundo non fuit dolor in Christo, quia nunquam fuit martyr, qui tantum informatus caritate desideraret mori, et ex hoc est meritum passionis' [In the second way (i.e. with respect to his rational will) there was no dolor in Christ, because he was never a martyr, but he was one who was informed by so much charity that he desired to die, and from this is the merit of the passion].

46 SH IV, P1, In1, Tr5, Q1, M3, C2 (n. 149), arg. 1, p. 209a: 'Et quod tanta fuerit humilitas, patet, quia Adam ascendere voluit ad deitatem, non in unione personae, sed per conformitatem scientiae. Sed Deus descendit usque ad unionem cum humana.'

47 SH IV, P1, In1, Tr5, Q1, M3, C2 (n. 149), Ad obiecta 1, p. 209 b.

48 For more on this aspect of the soteriology of the $S H$, see Boyd Taylor Coolman, 'The Salvific Affectivity of Christ according to Alexander of Hales,' The Thomist 71 (2001): 1-38.

49 SH IV, P1, In1, Tr5, Q1, M3, C2 (n. 149), Ad obiecta 1, p. 209 b. 
jection of the peace that he offers. These moments of suffering prior to his death on the cross are anticipations of the full rendering of satisfaction that occurs on in his death. ${ }^{50}$

The $\mathrm{SH}$ also argues that Christ's resurrection contributes to our redemption. The $\mathrm{SH}$ takes Rom. 4:25 as raising this issue when Paul writes, 'He died for our sins and rose for our justification. ${ }^{51}$ Thus, it seems that Paul teaches that Christ's resurrection is the cause of our justification whereas his death causes the forgiveness of sins. The $\mathrm{SH}$ holds that forgiveness of sins and justification imply one another. There can be no forgiveness apart from justification and no justification that does not involve cleansing a person from his sins. ${ }^{52}$ Thus, if the resurrection is the cause of justification, it will also be the cause of forgiveness. Moreover, as the $S H$ notes, interpreting Rom. 4:25 as denying that the death of Christ brings about our justification contradicts Rom. 3:24-25, which states that we are justified through faith in Christ's blood..$^{53}$

To resolve the questions raised by Rom. 4:25 the $S H$ draws on the Gloss of Peter Lombard. According to the Gloss, both Christ's death and resurrection take away our sins and justify us. Yet the Gloss states that there is a difference between the death and resurrection of Christ in regard to what they signify. The $\mathrm{SH}$ cites the following passage from the Gloss: 'the death of Christ alone signifies the destruction of our old life, and in the resurrection alone new life is signified. ${ }^{54}$ Thus, Christ's death is a sign of the remission of sins, but his resurrection is a sign of our justification. Rom. 4:25 connects the resurrection to our justification because of what it signifies, not because it is the sole cause of justification. Even though the death and resurrection are both causes of our justification, they bring this about in different ways. The passion is a cause of justification that brings about an incomplete justification in this life. While justification in this life destroys one's guilt for sin by the conferral of grace, justification in the next life will free a person from every sort of misery. It is the res-

50 SH IV, P1, In1, Tr5, Q1, M3, C2 (n. 149), Ad obiecta 1, p. 209b: 'Unde sicut ab elatione inchoavit peccatum Adae, ita fuit consummatio in comestionis delectatione. Eodem modo dispensatio nostrae redemptionis fuit in initio humilitatis incarnationis, progressus in conversatione, in qua passus est per compassionem, unde "flevit", Luc. 19, 41; consummatio vero fuit in passione, unde dixit: "Consummatum est"' [Just as the sin of Adam began from passion, so also was there consummation in the pleasure of eating. In the same way the dispensation of our redemption began from the humility of the incarnation, advanced through his living among us, during which period he suffered through compassion, whence "He cried" (Luke 19:41). But its consummation was in the passion, whence he said, "It is consummated"].

51 SH IV, P1, In1, Tr5, Q1, M6, C1, Ar1 (n. 156), arg. 1, p. 217 a.

52 SH IV, P1, In1, Tr5, Q1, M6, C1, Ar1 (n. 156), args 2-3 and Ad obiecta 2 and 3-5, p. 217a-b. 53 SH IV, P1, In1, Tr5, Q1, M6, C1, Ar1 (n. 156), arg. 5, p. 217b.

54 SH IV, P1, In1, Tr5, Q1, M6, C1, Ar1 (n. 156), Respondeo, p. 217b: 'mors tamen Christi sola interitum vitae veteris significat, et in sola resurrectione nova vita significatur.' 
urrection that is the cause of justification in that latter sense. ${ }^{55}$ Thus, the justification of sinners, the primary fruit of Christ's redemptive work, is also caused by Christ's resurrection.

\section{Conclusion}

While the SH supplements Anselm's narrow focus on Christ's death by its attention to how the Incarnation, life, and resurrection of Christ contribute to his redemptive work, it nevertheless relies on Anslem's $C D H$ at key moments in its treatment of redemption. Yet even in those places where the $S H$ seems most heavily dependent on Anselm-for example in its adoption of the category of satisfaction or its claim that certain aspects of the plan of redemption are necessary-we find the $\mathrm{SH}$ interpreting Anselm's claims in light of principles not taken from Anselm. Thus, satisfaction comes to be linked to punishment, and the 'necessity of immutability' is reformulated in light of the distinction between God's ordained and absolute power. The SH moreover frequently brings Anselm's ideas into dialogue with those of other theological authorities. In doing so the $S H$ produced an original synthesis of its sources that is especially apparent in its use of Anselm and Peter Lombard. Many of the texts cited about satisfaction are taken from $C D H$, but the particular way of interpreting the concept of satisfaction is heavily influenced by Peter Lombard's Sentences. Moreover, the way that Christ's merit comes to have equal importance to his satisfaction also reflects the influence of Peter Lombard. Given the interest of Alexander of Hales and his early disciples in promoting the study of both Anselm's $C D H$ and Peter Lombard's Sentences, it should perhaps be expected that the $S H$ would bring their teaching on redemption together in a creative way.

55 SH IV, P1, In1, Tr5, Q1, M6, C1, Ar1 (n. 156), Ad obiecta 2, p. 217b and SH IV, P1, In1, Tr6, Q1, M2, C2 (n. 172), p 244a-b. For more on the different types of causality exercised by Christ's resurrection, see SH IV, P1, In1, Tr6, Q1, M2, C1 (n. 171), pp. 241-3. 